\author{
LIDIA MARSZAŁEK \\ Pedagogium, Higher School of Social Sciences \\ Warsaw (Poland)
}

\title{
PRACTICAL PERSPECTIVE OF INTEGRAL VISION OF PRESCHOOL EDUCATION
}

Tytuł w języku polskim: Praktyczna perspektywa integralnej wizji edukacji przedszkolnej.

Streszczenie: Znaczącym wyzwaniem dla współczesnej pedagogiki przedszkolnej jest konieczność integralnej edukacji, przyjętej za przewodnią ideę wszelkich oddziaływań pedagogicznych. Wyzwanie to nie jest nowością zarówno dla przedszkolnej pedagogiki, jaki pedagogii - obie bowiem w swej najgłębszej istocie wyrastają z idei integralności i ideę tę realizują w różnorodnych formach i zakresach. Integralny charakter pedagogiki przedszkolnej w jej podstawowych założeniach implikuje tożsame odniesienia $\mathrm{w}$ obrębie przedszkolnej pedagogii, znajdując odzwierciedlenie w całej działalności przedszkola. Treści edukacji zakładają oprócz dostarczania dzieciom wiedzy o świecie i rozwijania ich sprawności intelektualnej również kształtowanie sprawności fizycznej i postaw prozdrowotnych, budzenie postaw prospołecznych zarówno w odniesieniu do rodziny, wspólnoty, jak też szerszych grup społecznych, wprowadzanie $\mathrm{w}$ świat wartości estetycznych, kształtowanie sfery emocjonalnej i kompetencji moralnych. Integracja treści edukacji opiera się więc o zasadę wielostronności, dbałości o właściwe relacje składników treści oraz doboru tychże treści z różnych dziedzin wychowania. Analiza współczesnej problematyki integralności człowieka dowodzi jednak, że w obszarach pedagogiki i pedagogii przedszkolnej pomija się niezwykle istotny wymiar człowieka - jego wymiar duchowy. Prezentowany artykuł stanowi próbę praktycznych odniesień do współczesnej pedagogii przedszkolnej w aspekcie stymulowania duchowego rozwoju dziecka jako sfery życiowej przestrzeni, pozwalającej mu na realizowanie własnego człowieczeństwa.

Słowa kluczowe: dziecko, wiek przedszkolny, edukacja przedszkolna, duchowość, rozwój integralny. 


\section{Introduction}

Education of a person should be a multidimensional and multidisciplinary process of supporting this person's creation and development. The necessity of integral (holistic) education, accepted as a leading idea for all pedagogical interactions, is an important challenge for modern pedagogy. This challenge is not new for both preschool education and pedagogy, which have their deepest origins in the idea of integrity and realise it in different forms and scopes.

The true integral education must result from one basic fact which is the meeting of two people - a child and a teacher, and the conditions of this meeting such as forms, methods, time and place. Integration of a child's activity takes place in various forms of expression, and not by mechanical combination of opposing contents. It is because the integration is "an inspiration and support coming from a teacher to wake up children's souls and help them have a rich internal life, to experience, act and communicate in different human communities"1. In education, integrity is a key notion understood as a process of combining knowledge and experience elements in one entirety, yet this entirety should not be treated as a sum of individual elements but a process of creating and revealing new meaning. This is where the relations between the individual elements become crucial. The process of creating the entirety in education is never closed and final, with great educational values (cognitive and pedagogical ones) lying in it ${ }^{2}$.

\section{Integration in preschool pedagogy and education}

One of the basic rules of preschool education is the rule of integration which emphasises the necessity to consider interdependence of children's developmental stages, exposed in various situations, and different fields of children's functioning. This rule also supports harmonious influence on children's development combining ideas from different fields of education with integration of educational and child-upbringing knowledge ${ }^{3}$. Integration in preschool education consists in becoming aware of relations between all the fields of knowledge, leading children to the synthesis of knowledge from different areas and presenting an integrated picture of the real world. It is a continuous process consisting of experiencing a specific circle of life phenom-

${ }^{1}$ M. Sawicki, Rozważania o szkole, KRAM Publ., Warsaw 2005, p. 83.

${ }^{2}$ Cf. J. Gnitecki, Wyzwalanie edukacji zintegrowanej w reformowanej szkole, [in:] Edukacja zintegrowana w reformowanej szkole, ed. H. Moroz, Oficyna Wydawnicza Impuls, Cracow 2001, p. 24.

${ }^{3}$ Cf. M. Kwiatowska, Pedagogika przedszkolna jako wiedza o kierowaniu rozwojem dzieci w instytucjach przedszkolnych, [in:] Podstawy pedagogiki przedszkolnej, ed. M. Kwiatowska, WSiP, Warsaw 1988, p. 59; A. Klim-Klimaszewska, Pedagogika przedszkolna. Nowa podstawa programowa, Instytut Wydawniczy ERICA, Warsaw 2012, p. 115; J. Karbowniczek, M. Kwaśniewska, B. Surma, Podstawy pedagogiki przedszkolnej z metodyka, WAM Publ., Cracow 2011, p. 290. 
ena and integration of the knowledge acquired by children during their present actions. It requires a skilful integration of the matter and methods in the scope of different subjects, starting with children's early experiences and their gradual widening. An integral character of preschool education, based on its main assumptions, implies similar references to preschool pedagogy, as reflected in the entire activity of kindergartens.

The process of content integration is supported in the preschool practice by a new tendency of interpretation of the programme content and adjusting it to children's expectations and needs, as well as matching the actual conditions which accompany the education - as opposed to the outdated habit of "implementation of the programme"4. Preschool education is the process which affects children's personality, taking into account not only the aspects of their natural development but also relations between upbringing, education and development ${ }^{5}$. Preschool pedagogical activity involves close integration of educational and upbringing processes so that they complement each other, which results in multidimensional participation of children in actions and experiences. Guiding children's activity enriches their knowledge, skills and abilities and, at the same time, it shapes their moral, aesthetic and social backbones, as well as their habits related to social interactions. Knowledge acquired by children in kindergartens is supposed to open them to learning, experiencing and understanding the world, especially the things which are good and beautiful.

Integration in pedagogical practice also takes place in other aspects and fields: forms and methods of acting, combining family and kindergarten environments in children's educational process, taking into consideration a holistic view of a child in all pedagogical actions with the necessity to think about interdependence of children's somatic and psychological development in every single situation (the influence of their health and frame of mind on their behaviour, the influence of emotional experiences, games and other forms of activity on functioning of their whole body, etc.).

Thus, it may seem that preschool education, along with its practical dimension, fully meets the requirements of the education combining all the spheres of children's existence. However, an analysis of the issues related to the modern human integrity proves that we often forget about a very important dimension - the spiritual one - in the fields of preschool pedagogy and education. Children's development, if it is to be comprehensive, must cover every aspect of their personality - not only the body, senses, feelings, mind, imagination and will but also their spiritual sphere. It is crucial for upbringing and educational processes to treat children in a holistic way as much as it is possible, to treat them as wholes (bio-psycho-social-spiritual beings) and, as a result, to pay attention to the theory which addresses the spiritual aspect of human

\footnotetext{
${ }^{4}$ Cf. J. Karbowniczek, M. Kwaśniewska, B. Surma, Podstawy pedagogiki..., op. cit., p. 106.

${ }^{5}$ Cf. R. Więckowski, Pedagogika wczesnoszkolna, WSiP, Warsaw 1998, p. 9.
} 
life, introducing it to all social areas, especially to education ${ }^{6}$. Thus, there must be a place for a spiritual aspect of integral education with holistic origins. It is because spirituality is the essence of human life and it is the way to develop awareness which goes beyond personal identity. The spiritual development is a part of life space of people, allowing them to realise their humanity and becoming the way to advance from duality to unity ${ }^{7}$. Modern preschool education, based on classic psychological developmental models - regardless of its declared broad influence - does not cover all the aspects of a child, vital for the integral growth and development. Scientific studies ignore children's spiritual sphere or assume it is irrelevant to the theory and practice of preschool education. Also, they agree that talking about spirituality with reference to children at preschool age would be a misinterpretation of the dimension in the view of psychological knowledge about this developmental stage. However, correct understanding of this notion in the context of above-mentioned psychological theories ${ }^{8}$ allows for isolating the aspects of children's functioning which prove that children at this stage of development are characterised by specific and natural spirituality in many areas of their activity.

\section{Practical implications of stimulating spiritual development of children at preschool age}

A specific way of experiencing material and non-material reality by children becomes the basis of their deep spirituality, which may be noticed in favourable conditions created during the process of development and education.

For development of children's spirituality, not only silence and concentration, their natural desire to contemplate the world with its material elements but also extrasensory perception are of crucial importance. Silence is the space for thoughts and experiencing; it is both the source and the result of concentration and surprise, which is also an important stimulus for the human spirit. Children at preschool age have something more than a natural ability to achieve the state of silent contemplation; it is their need which results from the special character of their spiritual experiencing. Contrary to appearances and accepted stereotypes, children do not need permanent physical and verbal activity whenever they attempt to activate their spiritual sphere.

${ }^{6}$ Cf. E.D. Białek, Zrównoważony rozwój dziecka w świetle nowych wyzwań, Oficyna Wydawnicza Impuls, Cracow 2009, pp. 13-15. Cf. also: W. Pasternak, Gtębia i pewność: o pedagogice teonomicznej u progu trzeciego tysiaclecia, PTP Scientific Publ., Poznań 1999; R. Assagioli, Psychosynthesis. A collection of basic writings, Synthesis Center, Amherst 2000.

${ }^{7}$ Cf. W. Pasternak, O pedagogice wyższych stanów świadomości, PTP Scientific Publ., Zielona Góra 2003, p. 12; idem, Świadomość jako inteligentna energia duchowa, [in:] O naturze świadomości: materiały ogólnopolskiego interdyscyplinarnego seminarium, PTP Scientific Publ., Cracow 1997, p. 72.

${ }^{8}$ Cf. P. Socha, Psychologia rozwoju duchowego - zarys zagadnienia, [in:] Duchowy rozwój człowieka. Fazy życia, osobowość, wiara, religijność, ed. P. Socha, Jagiellonian University Press, Cracow 2000, pp. 16-33. 
Such cases of "activation" are noticeable when children physically freeze in moments of silent astonishment and contemplation of the material and extrasensory world. Any efforts to explain, "make the observations deeper", provoking children to express their feelings, made by an adult at the moments of spiritual contemplation may distract this experience and dampen the children's activity in their spiritual sphere. Thus, the role of an adult is to respect this quality in children and to make it possible to exist - by creating proper conditions for a child to experience the world's phenomena in a direct way, resulting in surprise, astonishment and thoughtful observations which allow for the perception of these specific moments in children's everyday life without affecting their natural durability. This requires a specific individual approach to every child, which is not always possible under conditions of institutional education. That is why, in practice, we cannot always create a possibility to experience such contemplation if children sense something like this at the time and place we cannot foresee. Accepting the necessity to experience internal silence and contemplation by children implicates that organization of a routine kindergarten day must take this need into consideration - there must be enough time for children to experience the world through direct and real contacts, time to freeze in silent astonishment. At such moments a teacher should have a specially careful attitude in order not to distract children with excessive activity while explaining the world.

Using their deepest spiritual knowledge, by unspoken questions, children conceive notions which cover problems related to the meaning of life, existence of the world and people, they discover values and perfection in a way which is often deeper and more reflective than in the case of adults. Recognition of these qualities must induce an educator to adopt the attitude of special respect for the moments when children, contemplating material reality, de facto contemplate the highest values. This respect requires that pedagogues let children (and create conditions to) "be in their own time", in accordance with their own pace of experiencing - make children free from haste and excessive activity suggested or even organized by adults, accept silence, moments of "seclusion" and concentration.

Another important aspect of "revealing" a spiritual nature of children is the one related to aesthetic sensations. Contact with beauty and its internal experiencing reaches the deepest grounds of human spirituality, making people transcend the issues of ordinary functioning and stimulating their souls to open their existential profundity. However, children at preschool age are not mature enough for sophisticated works of art to make them experience the beauty in the deepest possible way. It is because they have a sense of aesthetics, typical for their age and perception of the world. But, due to their special sensitivity to colours and harmony, children can be deeply moved by encounters with works of art which treat them as the main carrier of their contents. Still, the most powerful aesthetic experiences are the ones which are related to nature: children can be astonished by its beauty, ranging from monumental landscapes to the 
tiniest elements of the world they are observing. Experiencing the beauty, children can attain the contemplation which awakens their spiritual sphere in a particular way.

Morality, a sphere which covers problems of good and evil as well as universal values related to the special character of humanity, is also a specific area for revealing children's spiritual sphere. It should be noticed that children's abilities to see the difference between good and evil, and even the desire to realise the good in their actions are much greater than the accepted assumptions of the modern developmental psychology. Children are good "by nature", thanks to their simplicity of feelings and actions (regardless of the ways we explain this phenomenon) but to keep this quality in their future lives they need to have the right personal exemplars, to experience love in their social surrounding, to be confident of their own moral intuition and find occasions to behave in the ethical way. Unfortunately, the modern preschool pedagogy addresses the range of problems related to moral education only to the smallest extent, supporting it with old theories and infantile set of expectations. It gives an impression that a kindergarten does not want to take advantage of children's abilities, which are exceptional in this field, to form people who can find their full humanity while selecting the good. Thus, the proper approach to this range of problems would require the verification of knowledge on children's actual abilities related to their moral sphere, as well as the extension of preschool education programmes to aspects which have been regarded as inaccessible to children at this age so far. The aspects should include creating occasions to behave according to the rule of supporting other people in their life difficulties or practise an ability to empathise intuitively with their psychological and spiritual conditions. The teachers who are aware of these natural abilities of children and who trust them in this matter would only have to trigger situations allowing these abilities to be revealed in children's everyday actions and motivating them to "show" these spiritual aspects of existence, instead of "implementing the values" and moralising. At the same time, the teachers should present a positive exemplar of behaviour, realising the universal values - Good, Truth and Beauty - in behaviour and attitude towards children. The exemplar should be an "unequivocal" and beautiful person in every aspect of life, regarding their moral qualities presented in the educational relations.

In this aspiration for integral preschool education we must not forget about stimulation of the development of children's emotional sphere. Children need appropriate ambience - full of kindness, goodwill and love in every environment of their existence, but children are also the source of these components which - if they are appropriately supported and shaped - become the basis not only of their spiritual relation with the world, but also the cognitive and moral one. The modern preschool education should consider this dimension of children's functioning - which is marginally acknowledged at present times - as broader, starting with verification of the present 
knowledge and understanding of children's feelings, since they are, by their nature, spontaneity and freshness, an exceptional phenomenon which is inimitable at any of the future developmental stages. Reinforcement of the nature of children's feelings (without determining the ways of their expression at this age) - sensitivity, gentleness and unconditional love to everything and everybody - is a chance to keep their special character to some extent in the future adult life and to lead children towards important values. Negligence in this area will result in the situation when "instead of people capable of feeling 'happiness' which [...] consists in internal harmony based on the ability to feel other people's joy and pain, there are more and more emotionally ignorant people who easily become a prey for different 'self-appointed experts surrounded by scientific prestige or exotic spirituality"',

Thus, there should be space and time in preschool pedagogy for the development of children's emotional intelligence combined with self-awareness. Children need help to see the nature of, understand and verbalise their own emotional experiences, they need to have the proper solutions presented to solve emotional conflicts and become aware of their right to experience a broad range of feelings and emotions. All these elements must be a part of those everyday actions and experiences which are the common ground for children's integral functioning. Children should have a chance to experience emotional conditions and this requires their direct participation in the events, exposure to the material and social phenomena, relations with nature, other people and art, from every possible aspect. The teachers' role in such relations is, first of all, to create conditions for these interactions in all environments which are the source of experience for children and the ground to reveal their feelings. Also, in the assumptions of preschool education and its practical dimension, there ought to be some prospect of providing children with a possibility to express the feelings they experience in socially accepted forms. Children's feelings should be greatly respected by adults but the ability to express them properly should be subject to "emotional education" - not in order to stop or hide them but to express them in an appropriate way, be it verbal, artistic or motor.

A special position in integral preschool education should also be taken by children's creativity - seen not only from its aesthetic aspect but also in the terms of the effects of their own work. Creativity is not only something that enriches children as people but in the shape of their work it greatly contributes to building spiritual culture of the community they live in. Thus, preschool education, aiming at children's integral development, must take creativity into consideration, not only to "supplement" their development but also to recognise it as one of the important areas in individual and social contexts.

${ }^{9}$ A. Murzyn, Prymat dziecka nad metodologia i organizacja. Wokót serii pedagogicznej "Nauczyciele - Nauczycielom", [in:] Dziecko w świecie wartości, part 2, ed. B. Dymara, M. Łopatkowa, M.Z. Pulinowa, A. Murzyn, Oficyna Wydawnicza Impuls, Cracow 2003, p. 255. 
The practical implication of this assumption forms a postulate to facilitate children's free creative activity at the time and in circumstances decided by them in a spontaneous way, not according to the "rule of executing a complex schedule" planned by teachers. The teachers' reflections related to children's creativity should also be complemented by an awareness of possible utilitarianism of such creative activity. It is because creativity is not only an important factor in revealing children's spiritual sphere, giving them a chance to "complete" experiences with their external expression, but it can also become an area to realise the children's goodness and moral beauty in a "perceptible" form because children's crafts bear the mark of their unconditional love for other people.

Discussing the concept of integral preschool education, we cannot forget about the importance of spontaneous play for the process of self-construction of children's identity. Spontaneous play is "the only space which gives children certainty of controlling themselves and the surrounding, feeling free - children teeter on the brink of the possible and the impossible, the permitted and the forbidden, swings and roundabouts, successes and failures"10. This fact, in addition to the knowledge about the essential quality of having fun, forces us to accept its crucial importance for preschool pedagogy, as it is an activity which makes it easier to reveal spiritual dimension of children's life. Spontaneous fun, besides having an unquestioned by educators influence on children's cognitive, social and physical development, is an activity of more and more perfect transgressions, of going beyond the physical and psycho-social abilities, revealing internal experiences and moving around the world of symbols in a mental and physical dimension. This special character of children's play makes it an exceptional occasion for revealing children's spiritual nature and for exercising their right to experience the world and themselves subjectively, without being unnecessarily corrected by the adults. It is "a permission to feel things at their source, to 'read them for the first time', to experience the accessibility of the world that is to be faced"11.

All the above remarks do not aspire to become a comprehensive methodological elaboration or "the only correct and possible" directives to construct the concept of preschool education. They are not an alternative for the present achievements of pedagogy in this field but rather, they are complementary for the modern educational theories and practices. The basic assumption is, first of all, an effort to provoke reflections on these fields of children's functioning which have been ignored so far and which are, in fact, a key factor in supporting children's integral development in all dimensions of their existence. Indication of possible practical organizational solutions and the necessity to redefine teachers' attitudes in the field of coexistence of children

${ }^{10}$ D. Waloszek, Pedagogika przedszkolna - metamorfoza statusu i przedmiotu badań, UP Scientific Publ., Cracow 2006, p. 282.

${ }^{11}$ Ibid., p. 281. 
and educationalists in preschool time is also of propositional character. It is to focus the attention of theoreticians, practitioners and officials - those who decide the shape of theoretical concept and its practical application in the process of education of children at preschool age - on children's specific qualities. Additionally, it is to emphasise the need not only to consider them while designing educational activities but also to pay special pedagogical attention to their significance and regard them while taking care of children's full development. "Understanding children as active constructors of their knowledge and identity, as critical thinkers with unlimited imagination, owners of many languages of expression, would allow them to improve the abilities to take active part not only in their own development but also in the development of the present and future society"12.

\section{Summary}

Accepting the above-mentioned assumptions as the leading and only possible ones in preschool practice is not, on one hand, possible from the point of view of its organization because of the limits of group education and, on the other hand, it would violate the rule of equal pedagogical influence on all the spheres of children's functioning. Concentration on a spiritual dimension of children's existence and depreciation of their physical, mental and social development in the context of their further social and physical life tasks would lead to another developmental imbalance. A human personality "covers at least three, completely opposite forms of existence: physical, psychological and spiritual. An individual limited to existence in the spiritual sphere becomes a mad, blind and deaf, [aware-of-nothing one]. The one limited to the psychological sphere becomes an unregulated clock [whose arms] do not point to anything. The one limited to existence on the physical level becomes nobody [but] a pile of ash. A person can exist only in motion between these extremes"13. Taking into consideration the fact of multidimensionality of a child must result in accepting the rule of multidisciplinary and complementary pedagogical influence which covers all the spheres of a child's functioning.

Children's integral development depends, first of all, on their possibilities to experience the world. This awareness implies such a character of educational influence which is based on activity, spontaneous actions in material and social world, freedom to experience it and also on discovering children's internal predispositions. "Any actions taken in the sphere of children's development must face the challenge to provide them with integrated and personalized interactions in order to facilitate acquisition of such experiences which make the conclusions related to children's individual

${ }^{12}$ G. Dalhlberg, P. Moss, A. Pence, Beyond quality in early childhood education and care. Postmodern perspectives, Routledge/Falmers, London 2001, p. 83.

${ }^{13}$ K. Obuchowski, Czlowiek intencjonalny, PWN Scientific Publ., Warsaw 1993, p. 89. 
personality, mentality and spirituality, resulting from their creativity and free will in this part of their unique individuality which is unmanaged by their environment"14. Innovative visions of preschool education ${ }^{15}$ seem to be especially valuable in this matter, complemented by the issues related to children's spiritual existence, which is now more genuine thanks to the fact that children are treated in a special way because of the strength of their developmental potential, individuality and inimitability. Those new visions can become a model of integral preschool pedagogy.

\section{Bibliography:}

Assagioli R., Psychosynthesis. A collection of basic writings, Synthesis Center, Amherst 2000.

Białek E. D., Zrównoważony rozwój dziecka w świetle nowych wyzwań, Oficyna Wydawnicza Impuls, Cracow 2009.

Dalhlberg G., Moss P., Pence A., Beyond quality in early childhood education and care. Postmodernperspectives, Routledge/Falmers, London 2001.

Gnitecki J., Wyzwalanie edukacji zintegrowanej w reformowanej szkole, [in:] Edukacja zintegrowana w reformowanej szkole, Moroz H. (ed.), Oficyna Wydawnicza Impuls, Cracow 2001.

Karbowniczek J., Kwaśniewska M., Surma B., Podstawy pedagogiki przedszkolnej $z$ metodyka, WAM Publ., Cracow 2011.

Karwowska-Struczyk M., Edukacja przedszkolna. W poszukiwaniu innych rozwiazań, Warsaw University Press, Warsaw 2012.

Klim-Klimaszewska A., Pedagogika przedszkolna. Nowa podstawa programowa, Instytut Wydawniczy ERICA, Warsaw 2012.

Kwiatowska M., Pedagogika przedszkolna jako wiedza o kierowaniu rozwojem dzieci w instytucjach przedszkolnych, [in:] Podstawy pedagogiki przedszkolnej, Kwiatowska M. (ed.), WSiP, Warsaw 1988.

Murzyn A., Prymat dziecka nad metodologia i organizacja. Wokót serii pedagogicznej "Nauczyciele - Nauczycielom", [in:] Dziecko w świecie wartości, part 2, Dymara B., Łopatkowa M., Pulinowa M.Z., Murzyn A. (ed.), Oficyna Wydawnicza Impuls, Cracow 2003.

Obuchowski K., Człowiek intencjonalny, PWN Scientific Publ., Warsaw 1993.

Pasternak W., Gtębia i pewność: o pedagogice teonomicznej u progu trzeciego tysiaclecia, PTP Scientific Publ., Poznań 1999.

\footnotetext{
${ }^{14}$ M. Karwowska-Struczyk, Edukacja przedszkolna. W poszukiwaniu innych rozwiazań, Warsaw University Press, Warsaw 2012, p. 38.

${ }^{15}$ Cf. D. Waloszek, Sytuacyjne wspieranie ..., op. cit.; J. Karbowniczek, M. Kwaśniewska, B. Surma, Podstawy pedagogiki..., op. cit.
} 
Pasternak W., O pedagogice wyższych stanów świadomości, PTP Scientific Publ., Zielona Góra 2003.

Pasternak W., Świadomość jako inteligentna energia duchowa, [in:] O naturze świadomości: materiały ogólnopolskiego interdyscyplinarnego seminarium, PTP Scientific Publ., Cracow 1997.

Sawicki M., Rozważania o szkole, KRAM Publ., Warsaw 2005.

Socha P., Psychologia rozwoju duchowego - zarys zagadnienia, [in:] Duchowy rozwój człowieka. Fazy życia, osobowość, wiara, religijność, Socha P. (ed.), Jagiellonian University Press, Cracow 2000.

Waloszek D., Pedagogika przedszkolna - metamorfoza statusu i przedmiotu badan, UP Scientific Publ., Cracow 2006.

Więckowski R., Pedagogika wczesnoszkolna, WSiP, Warsaw 1998.

Abstract: The necessity of integral education, accepted as a leading idea for all pedagogical interactions, is an important challenge for modern preschool education. This challenge is not new both for preschool education and pedagogy which have their deepest origins in the idea of integrity and realise it in different forms and scopes. An integral character of preschool education, based on its main assumptions, implies similar references to preschool pedagogy, as reflected in the entire activity of kindergartens. Education contents assumes that, besides coming to knowledge on the world and developing their intellectual skills, children also work on their physical abilities and health-oriented attitudes, learn some prosocial behaviours with reference to family, community and bigger social groups, they are acquainted with the world of aesthetic values and shape their emotional and moral competences. Thus, integration of education contents is based on the rule of variability, care for proper relations of the contents and their selection from different educational fields. However, an analysis of the issues related to the modern human integrity proves that we often forget about a very important dimension - the spiritual one - in the fields of preschool pedagogy and education. The presented article is an effort to make practical references to modern preschool education in the aspect of stimulation of children's spiritual development as the part of their life space which allows them to realise their own humanity.

Keywords: children, preschool age, preschool education, spirituality, integral development.

Lidia Marszalek - dr hab., profesor Pedagogium - Szkoły Wyższej Nauk Społecznych w Warszawie. Ważniejsze publikacje: Duchowość dziecka. Znaczenia, perspektywy, konteksty w pedagogice przedszkolnej (2013). Zainteresowania naukowe: pedagogika przedszkolna, dziecko w wieku przedszkolnym, integralny rozwój dziecka, specyfika rozwoju duchowego. Adres e-mail: lidia.marszalek@gmail.com 